\title{
Efektivitas Diklat Pengendalian OPT Tembakau melalui Metode Ceramah dan Praktek Langsung di Lapangan
}

\author{
Muhammad Sardin AK \\ Widyaiswara Bapeltanbun NTB
}

\begin{abstract}
Abstrak. Salah satu tantangan dalam pembangunan pertanian adalah adanya kecenderungan menurunnya produktivitas lahan. Disisi lain sumberdaya alam terus menurun sehingga perlu diupayakan untuk tetap menjaga kelestariannya. Demikian pula dalam budidaya tembakau, supaya budidaya tembakau dapat berkelanjutan, maka teknologi yang diterapkan harus memperhatikan faktor lingkungan, baik lingkungan fisik maupun lingkungan sosial, sehingga budidaya tembakau dapat berlanjut. Tanaman tembakau dahulu merupakan salah satu produk ekspor Indonesia tetapi karena berkurangnya lahan untuk perkebunan tembakau akibat perumahan dan komoditi tanaman yang lain maka produksi tembakau semakin berkurang. Produksi tembakau juga berkurang karena serangan hama dan penyakit dimana ada beberapa serangan yang sampai saat ini belum ada cara untuk mengatasi serangan tersebut karena serangan virus dan jamur. Pelatihan terhadap petani dilakukan pada tanggal 12 - 18 Nopember 2020 menggunakan metode ceramah dan Praktek Langsung di lapangan. Tujuan dari penelitian ini adalah mengetahui efektivitas model pelatihan menggunakan metode ceramah dan praktek langsung kepada petani Tembakau di 8 (Delapan) Kabupaten yang ada di NTB. Jumlah sampel yang digunakan sebanyak 15 orang dari petani Tembakau Peserta Diklat.Tehnik pengambilan sampel menggunakan metode purposive sampling. Penelitian dilakukan dengan memberikan pretest dan postest untuk mengetahui peningkatan pengetahuan petani, selanjutnya data tersebut dianalisis menggunakan analisis statistik non parametrik yaitu uji Wilcoxon Match Pairs Test. Hasil penelitian menunjukkan bahwa harga Z hitung pada uji Wilcoxon adalah -2,295 merupakan nilai mutlak. Selanjutnya pada taraf kesalahan 5\%, Z tabel = 1,64 sehingga Z hitung lebih besar dari Z tabel. Hal ini menunjukkan bahwa pelatihan petani menggunakan metode ceramah dan praktek langsung dilapangan efektif dalam meningkatkan pengetahuan dan keterampilan peserta pelatihan.
\end{abstract}

Kata kunci: efektivitas, pelatihan, pengendalian OPT Tembakau.

\section{PENDAHULUAN}

Tanaman tembakau dahulu merupakan salah satu produk ekspor Indonesia tetapi karena berkurangnya lahan untuk perkebunan tembakau akibat perumahan dan komoditi tanaman yang lain maka produksi tembakau semakin berkurang. Produksi tembakau juga berkurang karena serangan hama dan penyakit dimana ada beberapa serangan yang sampai saat ini belum ada cara untuk mengatasi serangan tersebut karena serangan virus dan jamur.

Selama ini produksi Tembakau nasional masih mengandalkan sawah irigasi, namun ke depan bila hanya mengandalkan Tembakau sawah irigasi akan menghadapi banyak kendala. Hal tersebut disebabkan banyaknya lahan sawah irigasi subur yang beralih fungsi ke penggunaan lahan non pertanian, tingginya biaya pencetakan lahan sawah baru dan berkurangnya debit air. Dilain pihak lahan kering tersedia cukup luas dan pemanfaatannya untuk pertanaman Tembakau gogo belum optimal, sehingga ke depan produksi Tembakau gogo juga dapat dijadikan andalan produksi Tembakau nasional.

Namun demikian untuk mewujudkan hal tersebut terutama dalam peningkatan produksi dan mutu hasil yang optimal masih dihadapkan pada berbagai permalahan di lapangan dikonsumsi dengan mutu yang lebih baik dan tidak berdampak negatif terhadap 
lingkungan. Menindak lanjuti tuntutan tersebut, sudah saatnya petani menjadi perhatian serius bagi pemerintah, salah satunya dengan meningkatkan pengetahuan dan ketrampilan petani.

Pengetahuan adalah hasil dari tahu dan ini terjadi setelah seseorang melakukan penginderaan terhadap suatu objek tertentu. Tanpa pengetahuan seseorang tidak memiliki dasar untuk mengambil keputusan dan enentukan tindakan terhadap masalah yang dihadapi. Faktor-faktor yang mempengaruhi pengetahuan antara lain adalah pendidikan, pekerjaan, umur, minat, pengetahuan dan informasi (Anonim, 2014).

Peningkatan pengetahuan petani dilakukan melalui berbagai metode. Menurut Hamalik (2005), secara umum pelatihan bertujuan untuk mempersiapkan dan membina tenaga kerja, baik struktural maupun fungsional, yang memiliki kemampuan dalam profesinya, kemampuan melaksanakan loyalitas, dedikasi dan disiplin yang baik.

Menurut Sastradipoera (2006) konsep pelatihan sebagai salah satu bentuk proses pembelajaran yang berhubungan dengan upaya pengubahan tingkah laku sumber daya manusia agar tingkah laku itu sesuai dan memadai untuk kebutuhan dan tujuan tertentu.

Salah satu metode yang digunakan dalam pendidikan dan pelatihan pertanian (Diklat Pertanian) adalah metode ceramah dan Praktek. Menurut Peraturan Menteri Pertanian Nomor : 49/Permentan/ OT.140/9/ 2011 tentang Pedoman Pendidikan dan Pelatihan Pertanian Aparatur dan Non Aparatur, metode ceramah adalah penyampaian informasi secara lisan kepada pelaku utama, pelaku usaha dan/atau tokoh masyarakat dalam suatu pertemuan. Menurut penelitian yang dilakukan oleh Ooi, et al. (2007), faktor yang paling berkontribusi terhadap efektivitas pelatihan adalah kompetensi trainer dan metode pelatihan. Hal ini diperkuat oleh penelitian yang dilakukan Haslinda (2009) bahwa kompetensi instruktur dan jenis pelatihan merupakan faktor yang signifikan berkontribusi terhadap efektivitas pelatihan. Menurut Suwarto (1999), efektivitas artinya adanya efek (pengaruh, akibat, dan kesan) pada penggunaan metode/cara, sarana/alat dalam melaksanakan aktivitas sehingga berhasil guna (mencapai hasil yang optimal). Melalui pelatihan diharapkan pengetahuan petani dapat meningkat sehingga petani dapat menerapkan pengendalian OPT secara terpadu dalam teknologi budidaya Tembakau ramah lingkungan.

Berdasarkan latar belakang tersebut di atas, maka perlu dilakukan penelitian yang bertujuan untuk mengetahui efektivitas model pelatihan menggunakan metode ceramah dan praktek yang diberikan kepada petani Tembakau di 8 (Delapan) Kabupaten yang ada di NTB. Keefektifan dapat juga diartikan suatu ukuran yang menyatakan seberapa jauh target (kuantitas, kualitas dan waktu) yang telah dicapai.

Dengan demikian semakin tinggi kadar keefektifan maka semakin tinggi pula tingkat capaian kuantitas, kualitas dan waktu pencapaianya (Anonim, 2014). Hasil dari penelitian ini selanjutnya dapat digunakan sebagai instrumen pendekatan dalam memperbaiki dan penyempurnaan program/kegiatan penyuluhan pertanian sehingga lebih efektif, efisien dan dapat mencapai tujuan yang telah ditetapkan.

\section{METODE PENELITIAN}

Penelitian dilaksanakan di Bapeltanbun pada tanggal 12 - 18 Nopember 2020. Populasi dalam penelitian ini adalah 15 petani Tembakau di Delapan Kabupaten yang ada di provinsi NTB. Pengambilan sampel sebanyak 15 petani Tembakau dilakukan secara sengaja (purposive sampling). Petani yang dipilih merupakan petani Tembakau yang sudah lama (turun temurun) melakukan budidaya Tembakau dengan teknik budidaya secara umum dan sederhana yaitu belum menggunakan teknologi ramah lingkungan khusus dalam pengendalian OPT Tembakau. 
Penelitian ini dilakukan dengan mengukur pengetahuan petani Tembakau sebelum dan sesudah mengikuti pelatihan dengan menggunakan metode ceramah dan praktek. Metode ceramah dan praktek yang dilaksanakan diperkaya dengan teknik-teknik pengaktifan peserta misalnya diskusi atau tanya jawab. Menurut Mujiman (2006), pelatihan dengan menggunakan metode ceramah dan praktek yang diperkaya dengan teknik-teknik pengaktifan peserta misalnya diskusi atau tanya jawab akan mengaktifkan dan memotivasi peserta dalam pemahaman dan penguasaan materi yang diberikan. Alat ukur yang digunakan dalam penelitian ini adalah kuisioner pretest dan postest.

Kuisioner berupa pertanyaan dengan penilaian secara skoring mengenai materi Pengendalian OPT Tembakau ramah lingkungan. Kuisioner pretest dan posttes yang digunakan sama. Pertanyaan yang digunakan sebagai variabel dalam pengukuran efektivitas pelatihan meliputi pengetahuan/pemahaman tentang: (i) Pengendalian Hama Terpadu; (ii) Cara mengidentifikasi OPT Tembakau; (iii) Jenis-jenis Hama Utama Tembakau; (iv). Jenisjenis Penyakit Utama Tembakau; (v). Teknikteknik Pengendalian OPT; (vi) Teknik Pengendalian OPT ramah lingkungan; (vii) Bahan-bahan untuk membuat pestisida nabati; (viii). Cara membuat pestisida nabati; (ix) Cara aplikasi pestisida Nabati; (x) Penggunaan Pestisida Kimia dan aplikasinya sesuai kaidah PHT; dan (xi) Dampak pengendalian OPT dengan pestisida kimia. Dari setiap varabel atau pertanyaan akan dilakukan skoring/penilaian dengan interval $1-3$ dengan kriteria, skor 1 menunjukkan nilai tinggi, skor 2 menunjukkan nilai sedang, dan skor 3 menunjukkan nilai rendah.

Pelatihan dilakukan selama empat hari dan setiap hari berlangsung selama delapan jam pelajaran dimulai jam $08.00-15.00$ WIT. Materi yang disampaikan berupa Pengendalian Hama Terpadu (PHT), Identifikasi OPT, Pengamatan OPT, Teknik Pengendalian OPT
Tembakau. Hasil kajian dan dijadikan rekomendasi teknologi yang meliputi: pengertian, tujuan dan manfaat pengendalian hama terpadu, cara mengidentifikasi OPT, Jenis-jenis OPT (Hama,Penyakit dan Gulma) Utama Tembakau, Metode pengamatan OPT, Teknik pengendalian (Fisik/mekanik, Biologi dan Kimia, Pengendalian ramah lingkungan dengan Pestisida Nabati. Bahan dan Cara membuat dan aplikasi pestisida nabati dan dampak penggunaan Pestisida Kimia.

Data primer yang dihimpun terdiri dari karakteristik responden dan hasil pretest dan postest. Data dianalisis dengan perangkat lunak aplikasi SPSS 17, menggunakan analisis statistik, dengan uji Wilcoxon Match Pairs Test (Siegel, 1994 dan Sugiyono, 2010). Uji ini digunakan untuk mengetahui perbedaan pengetahuan peserta antara sebelum dan sesudah diberikan pelatihan.

\section{HASIL DAN PEMBAHASAN Keragaan Responden}

Responden dalam penelitian ini adalah peserta pelatihan, yaitu petani Tembakau dari 8 (Delapan) Kabupaten yang ada di NTB. Responden semua berjenis kelamin laki-laki sebanyak 15 orang, terdapat pula keragaman karakteristik responden dari aspek usia dan pendidikan (Tabel 1).

Berdasarkan Tabel 1 seluruh responden, secara umum masuk dalam rentang usia produktif antara 15 - 64 tahun adalah sebanyak 13 responden, sedangkan 2 responden sudah masuk usia non produktif (68 tahun). Untuk tingkat pendidikan sebanyak 73,3 persen responden adalah SLTA dan sisanya adalah SD, SMP, D3 dan Sarjana (S1) dan Pascasarjana (S2).

Sebagian besar responden merupakan petani Tembakau yang telah memiliki pengalaman berusahatani cukup lama. Namun demikian penerapan berusahatani dilakukan secara turun temurun sehingga belum menerapkan budidaya ramah lingkungan. Mardikanto (2009) dalam bukunya tentang 
654actor penyuluhan pertanian menyebutkan bahwa karakterisitik penerima manfaat (petani) pada kegiatan pendidikan dan pelatihan sangat menentukan dalam pemahaman dan pengetahuan petani yang meliputi: (i) karakterisktik pribadi (jenis kelamin, umur, suku/etnis, dan agama); (ii) status 654actor ekonomi.(tingkat pendidikan, tingkat pendapatan, dan keterlibatan dalam kelompok); (iii) perilaku keinovasian; dan (iv) moral 654actor (petani subsisten atau petani komersial). Usia responden yang sebagain besar masuk dalam kategori usia produktif lebih cenderung memiliki sifat keinovasian dan motivasi yang tinggi dalam adopsi inovasi teknologi baru. Lama berusaha tani juga menentukan pemahaman terhadap materi yang berikan, responden tinggal membandingkan dengan apa yang telah dilakukan dengan teknologi baru. Pemahaman tentang teknologi baru dapat diperkuat melalui diskusi antara nara sumber dan petani (responden) sehingga dapat menyakinkan dalam penerapan teknologi baru yang disampaikan. Moral 654actor petani (responden) sebagai petani komersial juga menjadi 654actor penentu dalam adopsi teknologi baru, yaitu keinginan untuk mendapatkan keuntungan dari penerapan teknologi baru; dibandingkan dengan petani subsisten yang hanya mengandalkan teknologi turun temurun, tanpa ada inovasi dalam pengembangan teknologi dalam berusaha tani.

Tabel 1. Karakteristik Petani Tembakau dari 8 (Delapan) Kabupaten yang ada di NTB.

\begin{tabular}{|c|c|c|c|c|r|}
\hline $\begin{array}{c}\text { Umur } \\
\text { (Thn) }\end{array}$ & Jmlh (Org) & $\begin{array}{c}\text { Tingkat } \\
\text { Pendidikan }\end{array}$ & Jumlah (Org) & $\begin{array}{c}\text { Lama Bertani } \\
\text { Thn) }\end{array}$ & Jumlah \\
\hline $15-35$ & 8 & SD & 1 & $5-20$ & 11 \\
\hline $36-46$ & 4 & SMP & 1 & $21-35$ & 2 \\
\hline $47-57$ & 2 & SLTA & 11 & $36-50$ & 2 \\
\hline $58-68$ & 1 & D3 & 1 & - & - \\
\hline- & - & S1 & 1 & - & - \\
\hline- & - & S2 & 1 & - & - \\
\hline
\end{tabular}

\section{Efektivitas Pelatihan}

\section{(Menggunakan Metode Ceramah Dan Praktek Langsung)}

Untuk mengetahui efektifitas model pelatihan menggunakan metode ceramah dan praktek dilakukan dengan pengisian kuisioner pretest oleh responden sebelum pelatihan dimulai. Peningkatan pengetahuan responden setelah pelatihan diukur menggunakan kuisioner posttest yang diisi oleh responden setelah pelatihan selesai dilaksanakan. Penilaian setiap materi pada kusioner dengan skoring, yaitu dengan nilai tertinggi 3 dan nilai terendah 1, kemudian nilai tersebut dijumlahkan sebagai nilai akhir. Hasil dari pengisian kuisioner pretest dan postest tersaji pada Tabel 2.

Tabel 2. Hasil Pre Test dan Post Test

\begin{tabular}{|c|c|c|}
\hline Responden & Pre Test & Post Test \\
\hline 1 & 67 & 80 \\
\hline 2 & 54 & 75 \\
\hline 3 & 67 & 66 \\
\hline 4 & 55 & 60 \\
\hline 5 & 87 & 78 \\
\hline 6 & 60 & 89 \\
\hline 7 & 70 & 65 \\
\hline 8 & 45 & 70 \\
\hline 9 & 54 & 68 \\
\hline 10 & 66 & 75 \\
\hline 11 & 73 & 74 \\
\hline 12 & 88 & 85 \\
\hline 13 & 80 & 89 \\
\hline 14 & 75 & 75 \\
\hline 15 & 65 & 90 \\
\hline Total & $\mathbf{1 . 0 0 6}$ & $\mathbf{1 . 1 3 9}$ \\
\hline Rata-rata & $\mathbf{6 7 , 0 7}$ & $\mathbf{7 5 , 9 3}$ \\
\hline & & \\
\hline
\end{tabular}

Data selanjutnya dianalisis dengan aplikasi SPSS 17, menggunakan analisis statistik nonparametrik yaitu dengan uji Wilcoxon Match Pairs Test. Hasil dari analisis data yang dilakukan tersaji pada Tabel 3 . Analisis data dilakukan dengan membandingkan nilai hasil pre test dan post test untuk menguji signifikansi dua subyek penelitian berpasangan (Ernawati, et al, 2012). Analisis uji Wilcoxon Match Pairs Test merupakan analisis pengujian efektivitas (Narbuko, 2004). 
4. Jenis-jenis Penyakit Utama Tembakau (P4);

5. Teknik-teknik Pengendalian OPT (P5);

6. Teknik Pengendalian OPT yang ramah lingkungan dengan Pestisida Nabati (P6);

7. Bahan-bahan untuk membuat pestisida ramah lingkungan pestisida nabati (P7);

8. Cara membuat Pestisida Nabati (P8);

9. Cara aplikasi Pestisida Nabati (P9);

10. Penggunaan Pestisida Nabati dan aplikasinya (P10); dan

11. Penggunaan Pestisida Kimia sesuai kaidah pengendalian organism secara terpadu (P11).

Perkembangan pengetahuan responden (petani) dapat dilihat dari perbedaan nilai yang diperloleh dari nilai masing-masing materi yang diberikan hasil dari penilaian pre test (sebelum mengikuti pelatihan) dan post test (setelah mengikuti pelatihan).

Tabel 4. Identifikasi Kebutuhan Diklat Teknis Pengendalian OPT Tembakau di Tingkat Petani dari 8 (Delapan) Kabupaten yang ada di NTB. melakukan identifikasi kebutuhan diklat dan analisa kebutuhan diklat (IKD dan AKD) ditingkat petani untuk mengetahui materi yang sesuai dengan kondisi di tingkat petani tentang permasalahan di lapangan yang sangat mendesak untuk diatasi. Dari data AKD tersebut secara umum, responden (petani) belum menggunakan teknik pengendalian Hama Terpadu dalam budidaya Tembakau. Perbedaan teknik PHT dalam budidaya Tembakau dan teknik pengendalian biasa di tingkat petani yang disampaikan pada pelatihan dapat dilihat pada Tabel 4.

Materi yang diberikan dalam pre test dan post test merupakan pertanyaan tentang budidaya Tembakau dan teknik pengendalian OPT ramah lingkungan secara umum. Materi yang digunakan sebagai variabel/pertanyaan dalam pengukuran efektivitas pelatihan meliputi pengetahuan/pemahaman tentang halhal sebagai berikut:

1. Pengendalian Hama Terpadu (P1);

2. Cara mengidentifikasi OPT Tembakau (P2);

3. enis-jenis Hama Utama Tembakau (P3);

\begin{tabular}{|l|l|l|l|}
\hline No & $\begin{array}{l}\text { Kebutuhan Diklat } \\
\text { Teknis }\end{array}$ & $\sum$ Resp & $(\%)$ \\
\hline 1. & Persiapan Lahan & 0 & 0 \\
\hline 2. & Perbenihan & 2 & 13,3 \\
\hline 3. & Penanaman & 0 & 0 \\
\hline 4. & $\begin{array}{l}\text { Pemeliharaan : } \\
- \text { Pemupukan } \\
- \text { Pengairan } \\
- \text { Pengendalian }\end{array}$ & 1 & 6,6 \\
OPT & 12 & $\begin{array}{l}0 \\
80,0\end{array}$ \\
\hline 5. & $\begin{array}{l}\text { Panen } \\
\text { Penanganan pasca } \\
\text { panen }\end{array}$ & 0 & 0 \\
\hline
\end{tabular}

Sumber: Data Analisa Kebutuhan Diklat, (2017)

Berikut peningkatan pengetahuan peserta pelatihan hasil pre test dan post test dapat dilihat pada Tabel 5 .

Tabel 5. Perkembangan Pengetahuan Petani Berdasarkan Materi Pre Test Dan Post Test Yang Di Berikan.

\begin{tabular}{|c|c|c|c|}
\hline Materi & $\begin{array}{l}\text { Post } \\
\text { Test }\end{array}$ & Pretest & Selisih \\
\hline P1 & 31 & 58 & 46,55 \\
P2 & 22 & 59 & 62,71 \\
P3 & 23 & 57 & 49,65 \\
\hline
\end{tabular}


Jurnal Ilmu Sosial dan Pendidikan

http://ejournal.mandalanursa.org/index.php/JISIP/index

Terakreditasi Peringkat 5 (No. SK: 85/M/KPT/2020)

\begin{tabular}{|c|c|c|c|}
\hline P4 & 21 & 58 & 63,79 \\
P5 & 28 & 58 & 51,71 \\
P6 & 31 & 59 & 47,46 \\
P7 & 31 & 58 & 46,55 \\
P8 & 27 & 58 & 53,45 \\
P9 & 22 & 59 & 62,71 \\
P10 & 29 & 59 & 50,85 \\
P11 & 27 & 59 & 54,24 \\
\hline Jumlah & 262 & 642 & 54,52 \\
\hline
\end{tabular}

Dari Tabel 5 dapat dilihat bahwa ratarata pengetahuan responden (petani) mengenai pengendalian OPT dalam budidaya Tembakau setelah pelatihan mengalami peningkatan sebesar 54,52 persen. Peningkatan pengetahuan petani melalui pelatihan ini tidak terlepas dari peran dari narasumber yang berkompeten dalam memberikan materi tentang teknik pengendalian OPT Tembakau, hal ini diperkuat oleh penelitian yang dilakukan Haslinda et al. (2009) dalam Tri Cahyo Mardiyanto dan Tri Reni Prastuti, 2010. bahwa kompetensi instruktur merupakan faktor yang signifikan berkontribusi terhadap efektivitas pelatihan. Fasilitator yang menyampaikan materi berasal dari Alumni TOT Benih Tanaman Hortikultura yang di laksanakan oleh BBPP Ketindan Jawa Timur yang terdiri dari Widyaiswara, Penyuluh dan POPT dari Balai Proteksi Tanaman Pertanian Perkebunan NTB. yang merupakan tenaga-tenaga yang memiliki kompetensi di bidang pengendalian hama dan penyakit tanaman hartikultura. Peserta pelatihan yang merupakan petani yang berpengalaman dalam budidaya Tembakau juga merupakan faktor penting yang berpengaruh dalam meningkatnya pengetahuan peserta pelatihan, sebagaimana yang disampaikan Anonim (2014) bahwa faktor -faktor yang mempengaruhi pengetahuan antara lain adalah pendidikan, pekerjaan, umur, minat, pengetahuan dan informasi.

Setelah pelaksanaan pelatihan, selain diberikan pertanyaan dalam post test, reponsden (petani) juga diminta untuk memberikan penilaian terhadap materi untuk mengetahui sikap dan respon selanjutnya.
Vol. 4. No. 4 November 2020

p-ISSN: 2598-9944 e- ISSN: 2656-6753

Penilaian diberikan terkait dengan: manfaat materi yang diberikan, kemudahan materi untuk diterapkan, kelebihan keuntungan yang didapat dalam penerapan materi, kesesuaian materi dengan kebutuhan usahatani, kesukaan atau ketertarikan terhadap materi yang diberikan, keinginan untuk menerapkan materi yang diberikan, dan rencana penerapan materi yang telah diberikan (Tabel 6).

Tabel 6. Sikap dan Ketertarikan terhadap Materi.

\begin{tabular}{|c|c|c|c|c|}
\hline No & Kriteria & Skor & $\sum_{\text {Resp }}$ & $(\%)$ \\
\hline 1. & Manfaat materi & $\begin{array}{l}1-1,66 \\
1,67-2 \\
2,34-3 \\
\end{array}$ & $\begin{array}{l}0 \\
0 \\
15 \\
\end{array}$ & $\begin{array}{l}0 \\
0 \\
100 \\
\end{array}$ \\
\hline 2. & $\begin{array}{l}\text { Kemudahan } \\
\text { materi } \\
\text { diterapkan } \\
\end{array}$ & $\begin{array}{l}1-1,66 \\
1,67-2 \\
2,34-3 \\
\end{array}$ & $\begin{array}{l}0 \\
1 \\
14 \\
\end{array}$ & $\begin{array}{l}0 \\
0,6 \\
93 \\
\end{array}$ \\
\hline 3. & $\begin{array}{l}\text { Kelebihan dan } \\
\text { kekurangan } \\
\text { yang di peroleh } \\
\text { ketika } \\
\text { materi } \\
\text { diterapkan }\end{array}$ & $\begin{array}{l}1-1,66 \\
1,67-2 \\
2,34-3\end{array}$ & $\begin{array}{l}0 \\
2 \\
13\end{array}$ & $\begin{array}{l}0 \\
13 \\
86\end{array}$ \\
\hline 4. & $\begin{array}{l}\text { Kesesuaian } \\
\text { materi } \\
\text { dengan } \\
\text { kebutuhan } \\
\text { usahatani } \\
\end{array}$ & $\begin{array}{l}1-1,66 \\
1,67-2 \\
2,34-3\end{array}$ & $\begin{array}{l}0 \\
0 \\
15\end{array}$ & $\begin{array}{l}0 \\
0 \\
100\end{array}$ \\
\hline 5. & $\begin{array}{l}\text { Ketertarikan } \\
\text { pada materi }\end{array}$ & $\begin{array}{l}1-1,66 \\
1,67-2 \\
2,34-3 \\
\end{array}$ & $\begin{array}{l}0 \\
0 \\
15\end{array}$ & $\begin{array}{l}0 \\
0 \\
100 \\
\end{array}$ \\
\hline 6. & $\begin{array}{l}\text { Keinginan } \\
\text { menerapkan } \\
\text { materi }\end{array}$ & $\begin{array}{l}1-1,66 \\
1,67-2 \\
2,34-3 \\
\end{array}$ & $\begin{array}{l}0 \\
0 \\
15 \\
\end{array}$ & $\begin{array}{l}0 \\
0 \\
100 \\
\end{array}$ \\
\hline 7. & $\begin{array}{l}\text { Rencana } \\
\text { menerap-kan } \\
\text { materi }\end{array}$ & $\begin{array}{l}1-1,66 \\
1,67-2 \\
2,34-3 \\
\end{array}$ & $\begin{array}{l}1 \\
2 \\
12 \\
\end{array}$ & $\begin{array}{l}0,6 \\
13 \\
80 \\
\end{array}$ \\
\hline
\end{tabular}

Ket : $1=$ rendah, $2=$ sedang, $3=$ tinggi

Tabel 6 menujukkan bahwa dari ketujuh kriteria sikap dan respon terhadap materi yang diberikan secara umum dinilai pada kategori tinggi yaitu 100 persen. Namun demikian untuk kriteria kemudahan materi dalam penerapannya 0,6 persen responden menilai pada kategori 
sedang. Hal ini menunjukkan bahwa responden (petani) belum terlalu yakin terhadap kemudahan dalam penerapan materinya, untuk itu, sebagai tindak lanjut dibutuhkan pendampingan dalam penerapan teknologi pengendalian OPT dalam budidaya.

Sementara itu, untuk kriteria kelebihan keuntungan yang didapat dalam penerapan materi, 13 persen responden menilai pada kategori sedang. Hal ini menunjukkan bahwa responden (petani) belum melihat langsung kelebihan keuntungan dalam penerapan materi.

Sebagai tindak lanjutnya akan dilakukan demplot sehingga petani akan dapat merasakan dan melihat langsung kelebihan dan keuntungan yang diperoleh dalam menerapkan teknologi pengendalian OPT dalam budidaya Tembakau ramah lingkungan.

Untuk kriteria rencana penerapan materi yang telah diberikan, 80 persen responden menilai pada kategori tinggi, 13 persen menilai pada kategori sedang, dan 0,6 persen menilai pada kategori rendah. Perbedaan Kategori ini berdasarkan pada tingkatan rencana responden (petani) dalam rencana penerapannya yaitu: (i) kategori tinggi artinya responden (petani) berencana akan mencoba menerapkan sendiri, mencoba menerapkan pada kelompok tani, dan menyampaikan kepada petani lain saat pertemuan kelompok; (ii) kategori sedang artinya responden (petani) berencana akan mencoba menerapkan sendiri dan di kelompok tani; dan (iii) kategori rendah artinya responden (petani) hanya berencana akan mencoba sendiri.

\section{KESIMPULAN}

Analisis uji Wilcoxon dengan membandingkan pengetahuan peserta pelatihan melalui pretes dan postes menunjukkan pelatihan secara signifikan meningkatkan pengetahuan peserta. Hasil penelitian membuktikan bahwa model pelatihan menggunakan metode ceramah dan praktek langsung lebih efektif dalam meningkatkan pengetahuan petani tentang teknologi pengendalian OPT Tembakau dari 8 (Delapan) Kabupaten yang ada di NTB.

Peningkatan pengetahuan responden (petani) setelah mengikuti pelatihan rata-rata sebesar 12,52 persen. Untuk sikap dan respon secara umum dinilai pada kategori tinggi yaitu: (i) manfaat materi yang diberikan sebesar 100 persen; (ii) kemudahan materi untuk diterapkan sebesar 90 persen; (iii) kelebihan keuntungan yang didapat dalam penerapan materi sebesar 70 persen; (iv) kesesuaian materi dengan kebutuhan usahatani sebesar 100 persen; (v) kesukaan atau ketertarikan terhadap materi yang diberikan sebesar 100 persen; (vi) keinginan untuk menerapkan materi yang diberikan sebesar 100 persen; dan (vii) rencana penerapan materi yang telah diberikan sebesar 60 persen.

\section{DAFTAR PUSTAKA}

Anonim. 2011. Peraturan Menteri Pertanian Nomor : 49/Permentan/ OT.140/9/ 2011 tentang Pedoman Pendidikan dan Pelatihan Pertanian Aparatur dan Non Aparatur. Kementerian Pertanian RI. Jakarta.

Anonim. 2014. Panduan Pelaksanaan dan Kumpulan Materi Training of Trainer (TOT) "Metodologi Pengkajian Penyuluhan dan Evaluasi Kinerja Diseminasi Hasil Litkaji bagi Penyuluh Pertanian Lingkup Balai besar Pengkajian dan Pengembangan Teknologi Pertanian (BBP2TP) Badan Penelitan dan Pengambangan Pertanian" Emawati, S., Lutojo, H. Irianto, T.H. Rahayu, I.A. Sari. 2012. Efektivitas model pelatihan keterampilan berbasis usaha pertanian-peternakan terpadu pasca bencana erupsi Gunung Merapi di Kecamatan Selo, Kabupaten Boyolali. Sains Peternakan 10 (2): 85 - 92.

Hamalik, O. 2005. Manajemen Pelatihan Ketenagakerjaan Pendekatan Terpadu: Pengembangan Sumber Daya Manusia. Jakarta: Bumi Aksara. 
Haslinda A. and M.Y. Mahyuddin. 2009. The effectiveness of training in the public service. American Journalof Scientific Research :39 - 51 .

Mujiman, H. 2006. Manajemen Pelatihan Berbasis BelajarMandiri. Yogyakarta: Pustaka Pelajar.

Narbuko. 2004. Metodologi Penelitian. Bumi Aksara.Jakarta.

. Bandung: Penerbit KappaSigma..

Siegel, S. 1994. Statistik Nonparametrik untuk Ilmu-ilmu Sosial. Jakarta: Gramedia Pustaka Utama.

Sugiyono. 2010. Statistik Nonparametrik untuk Penelitian.Bandung: Alfabeta.

Suwarto. 1999. Perilaku Keorganisasian. Yogyakarta: Universitas Atma Jaya Yogyakarta.

Tri Cahyo Mardiyanto dan Tri Reni Prastuti. 2010.Efektifitas Pelatihan Budidaya Tembakau Varietas Lokal Ramah Lingkungan dengan Metode Ceramah di Kabupaten Karanganyar.Jurnal DOI:10.18196/agr.2126 BPTP Jawa Tengah.
Ooi, Ai Yee. 2007. The Determinants of Training Effectivenessin Malaysian Organizations. International Journal ofBusiness Research.

Sastradipoera, K.. 2006. Pengembangan dan Pelatihan, SuatuPendekatan Manajemen 